\title{
BEECH LEAVES BRIQUETTES' AND STANDARD BRIQUETTES' COMBUSTION: COMPARISON OF FLUE GAS COMPOSITION
}

\author{
JIŘÍ RYŠAVÝ, JIŘÍ HORÁK, LENKA KUBOŇOVÁ, MIROSLAV JAROCH, FRANTIŠEK HOPAN, \\ KAMIL KRPEC \& PETR KUBESA \\ VSB - Technical University of Ostrava, Energy Research Centre, Czech Republic.
}

\begin{abstract}
Biomass stoves are not only popular, widespread and important sources of heat but are also not negligible sources of pollutants. The present study had two objectives in this field of research. The first one was to determine the difference between standard wooden and beech leaves briquettes flue gas composition during similar, standard home combustion conditions. The second objective was to determine the possibility of decreasing the mass concentration of pollutants contained in the flue gas produced by standard and alternative fuel combustion, i.e. wooden briquettes and beech leaves briquettes, by an oxidation catalyst. Significantly higher mass concentration of nitrogen oxides $\left(\mathrm{NO}_{\mathrm{x}}\right)$, almost 2.5 times higher, in the flue gas was observed during the beech leaves combustion. Both fuels reached the edge of actual legislation limit (European Standard Commission regulation [EU] 2015/1185) in case of mass concentration of carbon monoxide (CO). This issue was solved by a palladium-based catalyst with average degree of conversion around $82 \%$. The catalyst also influences flue gas composition from mass concentration of propane point of view with average degree of conversion around $15 \%$. The mass fraction of sulphur, occurring in the beech leaves briquettes, did not cause any issue to the catalyst in terms of its degree of CO conversion. Due to the test results from the beech leaves briquettes, i.e. high mass fraction of ash and high mass concentration of $\mathrm{NO}_{\mathrm{x}}$ in the flue gas, it is appropriate to use this kind of fuel as secondary fuel during the co-combustion process.

Keywords: beech leaves, biomass combustion, catalyst, flue gas purification.
\end{abstract}

\section{INTRODUCTION}

Despite the increasing search for modern and nearly unattended ways (e.g. using heat pumps) of heating in whole European Union (EU), the popularity of biomass combustion heating is still considerable [1,2]. Biomass combustion units for household heating are popular, widespread and important for reaching European renewable energy share targets [3]. Nowadays there are more than 70 million of solid fuel appliances for household heating in Europe [4]; in Czech republic alone there are approximately 500 thousand houses that are heated by solid fuels combustion [5]. These numbers include all kinds of biomass and coal appliances. Coal combustion for the household heating is decreasing because of many well-known reasons, namely fossil fuel with relatively high sulphur content and mercury content, but on the other hand, biomass consumption for the household heating in EU is still increasing. For example, in year 2018, the consumption of wood pellets was approximately 26.1 million tonnes, which was higher by about 2.1 million tonnes in comparison to that of 2017 [6]. The significantly increasing trend of pressed biomass combustion is obvious in many European markets, e.g. 
in year 2017, the consumption of wooden briquettes and pellets reached 210 thousand tonnes in Czech Republic and there was year-on-year increase by 20 tonnes (10\%) [7].

The reasons for the rising of popularity of pressed biomass (pellets and briquettes) combustion could be the high energy density, lesser storage place demand and no additional drying need after transportation to the customer. Nowadays, production of pressed biomass is limited by sawmills' capacity and consequently by the amount of produced sawdust [8].

The facts mentioned above encourage the search for alternative sources of suitable (waste) biomass for briquettes and pellets production. From the energy point of view, collected fallen leaves from the town's greenery are considered a relatively homogeneous biomass, suitable for further use, e.g. briquetting and pelleting.

The potential of usage of different kinds of leaves briquettes was observed in recent research works of Deepak et al. [9] (areca leaves), Khorasgani et al. [10] (oak leaves), Anggono et al. [11] (amboyna wood leaves), Biswas [12] (sugar cane leaves), Hardianto et al. [13] (amboyna pine leaves), Shiferaw et al. [14] (eucalyptus globulus leaves residues), Ushakov et al. [15] (black poplar leaves), Shuma et al. [16] (mopani leaves and sugar cane leaves), Malak et al. [17] (willow leaves) and Jittabut [18] (sugarcane leaves). In the mentioned research papers, ultimate and proximate analyses of different types of leaves were carried out, as well as investigations on the dependence of calorific value on carbonization temperature, physical properties and ignition temperature.

A recently published research of Yunfei et al. [19] describes the possibility of tobacco straw usage as the fuel for co-combustion with coal and finds this combination of fuels to be advantageous. A study of Hatmojo et al. [20] describes the possibility of leaf litter briquettes as an alternative energy source for cooking by combustion. The mentioned research showed that leaf litter in the form of briquettes has the potential to be considered as a reliable energy source for cooking in household at rural areas.

Possibilities of beech leaves briquettes usage as the stove fuel for household heating was observed by previous research of Ryšavý et al. [21]. In this work, beech leaves were collected, spontaneously dried, crushed and pressed into briquettes. These leaves/briquettes were subjected to proximate and ultimate analysis, thermogravimetric analysis and combustion tests in few years old, regularly used stove (Storch ESTELLI KERAMIK). The combustion tests demonstrated the possibility of meeting actual legislative limits, but the Commission regulation (EU) 2015/1185 [22] is much stricter; therefore, the described combustion equipment was not able to meet those limits with beech leaves briquettes, used as a fuel. This article expands on the earlier research by Ryšavý et al. [21].

All mentioned investigations confirm the relevance and importance of the topic of thermic utilization of alternative biomass fuels, especially the waste ones from the forestry and agriculture, which was not fully utilized before.

The thermic utilization of the solid fuels also includes gasification and pyrolysis processes. There is a potential to get higher overall efficiency of energy transformation from all kinds of biomass-based solid fuels. Also, there are some other advantages connected with the possibilities of syngas utilization, but there are also some issues with tar formation during the gasification process $[23,24]$.

The mentioned (unconventional) methods of solid fuels thermic utilization are especially suitable for middle and big scale energy systems (>100 kW) and require sophisticated devices and trained operators. The kind of connection of combustion and gasification processes is represented by wood gasification boilers and stoves, which partially transfer the issue of solid fuel combustion to gas fuel combustion. These kinds of devices can ensure higher efficiency of energy transformation under standard home conditions; they also ensure lower mass concentration of pollutants formed during the incomplete combustion process in the flue gas [25]. 
The main cause of high mass concentration of pollutants in the flue gas from the beech leaves briquettes' combustion was primarily a disintegration of briquettes on the grate. Disintegration of briquettes leads to non-sufficient approach of combustion air to the fuel and to creation of local high temperature anomaly.

The only method for decreasing the mass concentration of pollutants (from an incomplete combustion process) in the flue gas, without any construction intervention in the combustion equipment itself, is by using a catalyst as a secondary method for a flue gas purification. The flue gas temperature, measured during the beech leaves combustion tests in a previous study, ranged between 300 and $500^{\circ} \mathrm{C}$, which is a suitable operating temperature for oxidation catalysts based on precious metal active elements.

The positive influence of catalysts' usage on flue gas composition from wooden pellets combustion was observed by Ryšavý et al. in two studies [26,27]. The degrees of conversion of mentioned catalysts were up to $78 \%$ of carbon monoxide (CO) and $64 \%$ of organic gaseous carbon (OGC) in concrete conditions. Catalysts based on precious metals and metal oxides were tested. Both types proved to have significant influence on the mass concentration of pollutants, produced during an incomplete combustion process (CO and OGC). Precious metal-based catalysts were also observed by Reichert et al. [28]. These tested catalysts proved with the potential of $95 \%$ reduction of $\mathrm{CO}$ and $60 \%$ reduction of OGC in the flue gas, produced by wood log combustion in real-life operated stoves.

The novelty of the present study lies in a straight comparison of certified, widely used fuel with new (alternative) one from the mass concentrations of pollutants point of view. A novelty in this study lies also in the oxidation, palladium-based catalyst usage for the flue gas purification formed during an alternative fuel combustion which contains sulphur.

This study was focused on a combination of unconventional renewable fuel with unconventional solution for the flue gas purification to provide sustainable, cheap and environmentally friendly option for household heating.

\section{MATERIALS AND METHODS}

\subsection{Fuel}

For the combustion tests, two fuels were chosen. The first one was the beech leaves briquettes, which have been described in detail by Ryšavý et al. [21]. The second used fuel was standard wooden briquettes (with ÖNORM certification) made only from pure dry spruce shavings (bark and additional binders free). The results of proximate and ultimate analyses are shown in Table 1. The biggest difference between these two tested types of briquettes is in mass fraction of ash. The high amount of ash in the beech leaves briquettes (comparable to brown coal) and mass fraction of sulphur, occurring in their composition, are the biggest disadvantages. The mass fraction of nitrogen is also higher (approximately 3.6 times) than in the case of standard wooden briquettes. Lower mass fraction of oxygen in the beech leaves briquettes worsens the ignition process.

\subsection{Combustion equipment}

A small-scale stove Storch ESTELLI KERAMIK was chosen as a combustion equipment. The construction of chosen stove (simple design without any flue gas/water heat exchanger and without flue gas or air fan) ensures relatively high flue gas temperature at the flue gas outlet, which is crucial for proper catalyst operation. Additional heat exchangers (flue gas/ water or flue gas/air) may be placed in a flue gas duct behind the catalyst for additional 
Table 1: The results of proximate and ultimate analyses of beech leaves briquettes and standard wooden briquettes used for the combustion test.

\begin{tabular}{|c|c|c|c|c|}
\hline Element & $\begin{array}{l}\text { Chemical } \\
\text { symbol }\end{array}$ & Unit & $\begin{array}{l}\text { Beech leaves } \\
\text { briquettes }\end{array}$ & $\begin{array}{l}\text { Standard wooden } \\
\text { briquettes with } \\
\text { ÖNORM } \\
\text { certification }\end{array}$ \\
\hline Carbon & $\mathrm{C}^{\mathrm{r}}$ & $\%$ & 42.56 & 46.17 \\
\hline Hydrogen & $\mathrm{H}^{\mathrm{r}}$ & $\%$ & 4.62 & 5.37 \\
\hline Nitrogen & $\mathrm{N}^{\mathrm{r}}$ & $\%$ & 0.73 & 0.20 \\
\hline Oxygen & $\mathrm{O}^{\mathrm{r}}$ & $\%$ & 30.25 & 38.87 \\
\hline Sulphur & $\mathrm{S}^{\mathrm{r}}$ & $\%$ & 0.09 & 0 \\
\hline Water & $\mathrm{W}^{\mathrm{r}}$ & $\%$ & 8.87 & 8.58 \\
\hline Ash & $\mathrm{A}^{\mathrm{r}}$ & $\%$ & 12.88 & 0.79 \\
\hline Net calorific value & $\mathrm{Q}_{\mathrm{i}}$ & $\mathrm{MJ} \mathrm{kg}^{-1}$ & 15.64 & 17.00 \\
\hline
\end{tabular}

increase of the thermal efficiency. For this test, no additional heat exchanger was used. The nominal heat output of the chosen stove is $11 \mathrm{~kW}$. A sketch of the used stove with the location of installed catalysts is shown in Fig. 1.

The chosen combustion equipment was connected to the $7.5 \mathrm{~m}$ high chimney placed inside the laboratory. The chimney was constructed from polished brick chimney fittings and isostatic liners inside the fittings. The active part of the chimney was approximately $5.7 \mathrm{~m}$ high. The chimney was described in detail by Ryšavý et al. [29]. During the combustion test, only natural chimney draught was causing the flue gas suction from the stove, which was completely different from standard stove certification process. In the course of the certification process of the stove, an artificial chimney draught is caused by a flue gas fan. This test should have shown a real possibility of catalyst usage during the standard home operation.

\subsection{Measuring system for a flue gas analysis}

Flue gas was sucked from two sampling places of the flue gas duct (at the catalyst inlet and at the catalyst outlet). The same places served for flue gas relative pressure measurements. At first, flue gas samples were purified from solid particles on a glass wool filler. Then the flue gas went through a heated tube into two separated identical analysers MRU VARIO luxx. The mass concentrations of carbon monoxide $(\mathrm{CO})$, carbon dioxide, oxygen $\left(\mathrm{O}_{2}\right)$, nitrogen oxides $\left(\mathrm{NO}_{\mathrm{x}}\right)$ and propane $\left(\mathrm{C}_{3} \mathrm{H}_{8}\right)$ in the flue gas were determined by these devices. Prior to the combustion test, the analysers were justified by calibration gases. During the combustion test, OGC was not measured, except for $\mathrm{C}_{3} \mathrm{H}_{8}$ mentioned above. Propane is not a negligible part of OGC, but its absolute values could not be compared with the legislative OGC limits.

\subsection{Data evaluation}

The mass concentrations of each flue gas component, as well as flue gas temperature and its relative pressure, were recorded as average per each minute. All final values were counted as average values of mass concentration of the components (reported as mass concentrations in 


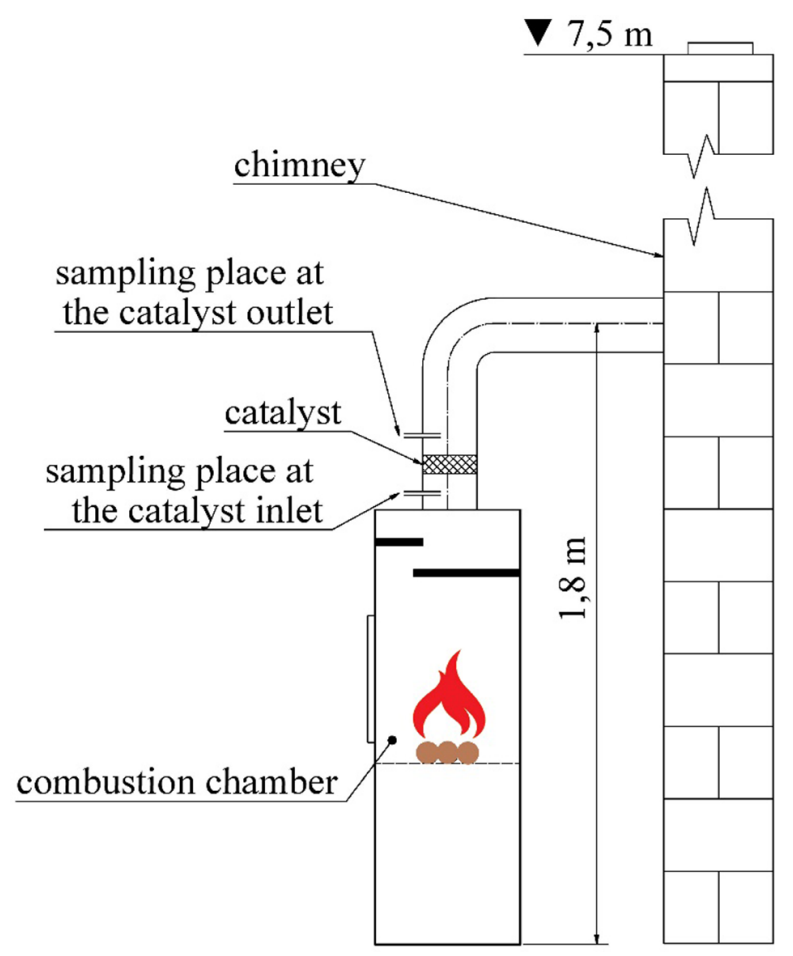

Figure 1: Sketch of used stove.

$\mathrm{mg} \cdot \mathrm{m}^{-3}$ ) in a dry flue gas, during the one combustion period. The final values were recalculated for standard conditions for temperature $T$ and pressure $p$ (STP conditions: $T=273.15 \mathrm{~K}$; $p=101,325 \mathrm{~Pa}$ ) and a reference volume fraction of oxygen in the flue gas $\varphi_{\text {ref; }[\mathrm{O} 2]}=13 \%$.

Degrees of conversion of the catalysts were calculated from a comparison of the mass concentrations of pollutants in the flue gas at the catalyst inlet and at the catalyst outlet present according to eqn (1):

$$
X=\frac{\rho_{B O}-\rho_{B}}{\rho_{B O}}
$$

where $\mathrm{X}$ is the degree of conversion of a pollutant as flowing through the catalyst (\%), $\rho_{B O}$ the mass concentration of a pollutant at the catalyst inlet $\left(\mathrm{mg} \cdot \mathrm{m}^{-3}\right)$ and $\rho_{B}$ the mass concentration of a pollutant at the catalyst outlet $\left(\mathrm{mg} \cdot \mathrm{m}^{-3}\right)$.

\subsection{Combustion test}

For ignition and heating the stove, $1.5 \mathrm{~kg}$ of standard wooden briquettes was used. The first test starts when the basic firebed was made. The combustion tests were divided into six consecutive modes, three modes with standard wood briquettes (mode 1, mode 3 and mode 5) and three modes with beech leaves briquettes (mode 2, mode 4 and mode 6 ). This fuel changing was crucial for determination of the flue gas composition difference between these two chosen fuels during comparable combustion conditions. Before each addition of the fuel, the basic firebed was raked through, causing part of the ash to fall into the ashtray. This act was 
necessary due to high mass fraction of ash in the beech leaves briquettes. According to the shape of beech leaves briquettes, which is given by the briquetting machine, and lower tendency to its internal strength (which caused the individual briquettes to be relatively small), it was necessary to add at least 12 pieces to reach overall weight of one batch of approximately $1,500 \mathrm{~g}$ (weights of all batches ranged around 1,500 $\mathrm{g} \pm 10 \mathrm{~g}$ ). In case of standard wooden briquettes, two, seven and eight pieces of briquettes were added to one batch. These pieces were cut off from standard briquettes shape ( $\sim 0.1 \mathrm{~m}$ diameter; $\sim 0.3 \mathrm{~m}$ length). The main reasons for cutting the standard briquettes were the small area of the grate (two pieces) and induction of similar conditions of the combustion process, as during the beech leaves briquettes' combustion (seven and eight pieces).

Always about 2 min after batch adding, a combustion air inlet flap was set to the operating position which was chosen according to operator experiences with this type of stove, to get the best flue gas composition from mass concertation of pollutants point of view. This position was not changed until the end of the mode. Each mode was terminated when only a hot basic layer of carbon without visible flames was left on the grate (approximately of the same layer thickness as before the previous fuel adding). Subsequently, the process was repeated in the next mode.

The test time of each mode was affected by the number of pieces of the fuel batch since it is closely related to the reacting surface of the fuel batch.

\subsection{Tested catalyst}

Detailed description of tested catalyst (referred to only as CAT A in what follows) is given in Table 2. A picture of tested catalyst CAT A is shown in Fig. 2. The producer of the catalyst

Table 2: Detailed description of used catalyst.

\begin{tabular}{lll}
\hline Marking & - & CAT A \\
Producer & & Whitebeam \\
Catalyst's type & - & Monolithic - honeycomb \\
Body (substrate) material & - & cordierite \\
Active compound & - & $\mathrm{Pd}$ \\
Precious metal loading & $\mathrm{g} \mathrm{dm}^{-3}$ & 0.619 \\
Shape & - & cylindrical \\
Main dimension & $\mathrm{m}$ & $\emptyset 0.144$ \\
Height & $\mathrm{m}$ & 0.051 \\
Volume & $\mathrm{m}^{3}$ & 0.00083 \\
Active surface & $\mathrm{m}^{2}$ & 0.56373 \\
Number of cells & $\mathrm{cells} \mathrm{cm}^{-2}$ & 4.14 \\
Pressure loss & $\mathrm{pa}$ & $<1$ \\
Cell inlet surface & $\mathrm{pa}^{2}$ & 0.0000168 \\
Number of cells & - & 674 \\
\hline
\end{tabular}

a The average catalyst's pressure loss during the combustion tests. 


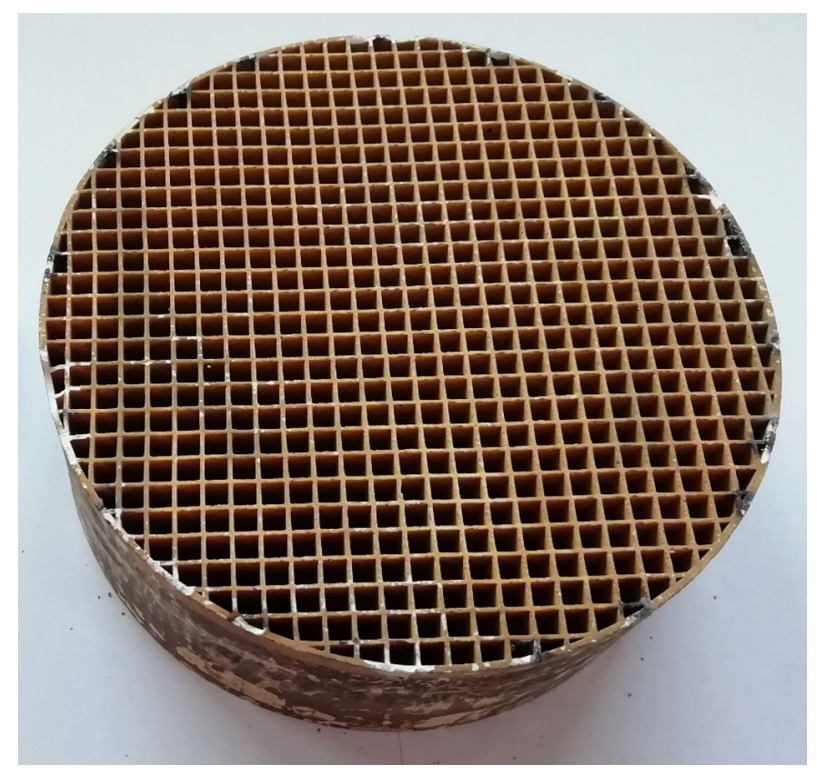

Figure 2: Tested catalyst CAT A.

did not provide information about suitable operating temperature of the catalyst. A thickness of the catalyst's active element layer was not observed and no information was provided by the producer. The producer also did not provide a conversion efficiency diagram of the observed catalyst for oxidation reaction of $\mathrm{CO}$ and OGC.

\section{RESULTS AND DISCUSSION}

The most important overall measured values are presented in Table 3. The final values of the mass concentrations of pollutants were recalculated for STP conditions and a reference volume fraction of oxygen in the flue gas $\left(\varphi_{\text {ref; [02] }}=13 \%\right)$. The final value of mass concentration of $\mathrm{NO}_{\mathrm{x}}$ is recalculated to $\mathrm{NO}_{2}$.

\subsection{Fuels comparison}

From the mass concentration of $\mathrm{CO}$ point of view, the flue gas produced during the standard wooden briquettes' combustion reached (on average) lower values (by approximately 28\%) than during the beech leaves briquettes' combustion. An average value of mass concentration of $\mathrm{CO}$ during the modes 1,3 and 5 was $1,256 \mathrm{mg} \cdot \mathrm{m}^{-3}$ (values ranged between $1,052 \mathrm{mg} \cdot \mathrm{m}^{-3}$ and $1,618 \mathrm{mg} \cdot \mathrm{m}^{-3}$ ), and an average value of mass concentration of $\mathrm{CO}$ during the modes 2,4 and 6 was $1,751 \mathrm{mg} \cdot \mathrm{m}^{-3}$ (values ranged between $1,089 \mathrm{mg} \cdot \mathrm{m}^{-3}$ and 2,390 $\mathrm{mg} \cdot \mathrm{m}^{-3}$ ). The most significant difference was made between mode 5 and mode 6. Modes 1 and 2, and 3 and 4 were comparable.

Values in accordance to Commission regulation (EU) 2015/1185 are marked green and those not in accordance with this regulation are marked red. BLB: beech leaves briquettes; $\mathrm{nm}$ : not measured; WB: wooden briquettes.

As can be seen in measured values of modes 3,4 and 5, the three lowest concentrations were reached during the combustion of 2 and 8 pieces of wooden briquettes and 12 pieces of 
Table 3: Overall results.

\begin{tabular}{|c|c|c|c|c|c|c|c|c|}
\hline \multicolumn{2}{|l|}{ Mode number } & & 1 & 2 & 3 & 4 & 5 & 6 \\
\hline \multicolumn{2}{|l|}{ Test time } & $\mathrm{h}$ & 0.7 & 0.8 & 1.0 & 0.8 & 0.8 & 0.8 \\
\hline \multicolumn{2}{|c|}{$\begin{array}{l}\text { Number of briquettes } \\
\text { pieces }\end{array}$} & pcs & $7 \mathrm{pcs}$ & 12 pcs & $2 \mathrm{pcs}$ & $12 \mathrm{pcs}$ & $8 \mathrm{pcs}$ & $12 \mathrm{pcs}$ \\
\hline \multicolumn{2}{|l|}{ Type of fuel } & - & WB & BLB & WB & BLB & WB & BLB \\
\hline \multicolumn{2}{|c|}{$\begin{array}{l}\text { Average heat output during } \\
\text { the mode }\end{array}$} & $\mathrm{kW}$ & 7.5 & 6.2 & 4.8 & 5.9 & 6.8 & 6.1 \\
\hline \multicolumn{2}{|l|}{ Fuel consumption } & $\mathrm{kg} / \mathrm{h}$ & 2.22 & 2.01 & 1.48 & 1.88 & 2.01 & 2.00 \\
\hline \multicolumn{2}{|l|}{ Power input } & $\mathrm{kW}$ & 10.5 & 8.7 & 7.0 & 8.2 & 9.5 & 8.7 \\
\hline \multicolumn{2}{|c|}{$\begin{array}{l}\text { Seasonal space heating } \\
\text { energy efficiency }\end{array}$} & $\%$ & 61.5 & 61.1 & 59.3 & 61.5 & 61.2 & 59.9 \\
\hline \multicolumn{2}{|c|}{ Flue gas temerature } & ${ }^{\circ} \mathrm{C}$ & 347 & 351 & 323 & 334 & 319 & 309 \\
\hline \multicolumn{2}{|c|}{$\begin{array}{l}\text { Volume fraction of oxygen } \\
\text { in the flue gas }\end{array}$} & $\%_{\text {vol. }}$ & 11.6 & 11.9 & 13.4 & 12.3 & 12.9 & 13.5 \\
\hline \multicolumn{2}{|l|}{ Air excess ratio } & - & 2.22 & 2.30 & 2.77 & 2.41 & 2.60 & 2.79 \\
\hline \multicolumn{2}{|c|}{ Flue gas volume flow } & $\mathrm{m}^{3} / \mathrm{h}$ & 51.65 & 45.51 & 40.69 & 43.39 & 51.78 & 50.74 \\
\hline \multicolumn{2}{|l|}{ Space velocity } & $1 / \mathrm{h}$ & 62192 & 54799 & 48987 & 52246 & 62345 & 61092 \\
\hline \multicolumn{2}{|c|}{$\begin{array}{l}\text { Reference volume fraction } \\
\text { of } \mathrm{O}_{2} \text { in flue gas }\end{array}$} & $\%_{\text {vol. }}$ & 13 & 13 & 13 & 13 & 13 & 13 \\
\hline \multirow{5}{*}{$\begin{array}{l}\text { Mass } \\
\text { concentration of } \\
\text { pollutants in the } \\
\text { flue gas at the } \\
\text { catalyst inlet }\end{array}$} & $\mathrm{CO}$ & $\mathrm{mg} / \mathrm{m}^{3}$ & 1618 & 1774 & 1099 & 1089 & 1052 & 2390 \\
\hline & $\mathrm{NO}_{\mathrm{X}}$ & $\mathrm{mg} / \mathrm{m}^{3}$ & $\mathrm{~nm}$ & $\mathrm{~nm}$ & $\mathrm{~nm}$ & $\mathrm{~nm}$ & $\mathrm{~nm}$ & $\mathrm{~nm}$ \\
\hline & $\mathrm{SO}_{2}$ & $\mathrm{mg} / \mathrm{m}^{3}$ & $\mathrm{~nm}$ & $\mathrm{~nm}$ & $\mathrm{~nm}$ & $\mathrm{~nm}$ & $\mathrm{~nm}$ & $\mathrm{~nm}$ \\
\hline & $\mathrm{C}_{3} \mathrm{H}_{8}$ & $\mathrm{mg} / \mathrm{m}^{3}$ & 27 & 12 & 19 & 7 & 18 & 64 \\
\hline & $\mathrm{CO}_{2}$ & $\mathrm{~g} / \mathrm{m}^{3}$ & 157 & 161 & 161 & 160 & 161 & 161 \\
\hline \multicolumn{2}{|c|}{$\begin{array}{l}\text { Reference volume fraction } \\
\text { of } \mathrm{O}_{2} \text { in flue gas }\end{array}$} & $\%_{\text {vol. }}$ & 13 & 13 & 13 & 13 & 13 & 13 \\
\hline \multirow{5}{*}{$\begin{array}{l}\text { Mass } \\
\text { concentration of } \\
\text { pollutants in the } \\
\text { flue gas at the } \\
\text { catalyst outlet }\end{array}$} & $\mathrm{CO}$ & $\mathrm{mg} / \mathrm{m}^{3}$ & 172 & 293 & 232 & 244 & 188 & 419 \\
\hline & $\mathrm{NO}_{\mathrm{X}}$ & $\mathrm{mg} / \mathrm{m}^{3}$ & 106 & 299 & 167 & 344 & 142 & 376 \\
\hline & $\mathrm{SO}_{2}$ & $\mathrm{mg} / \mathrm{m}^{3}$ & 0 & 19 & 0 & 34 & 0 & 26 \\
\hline & $\mathrm{C}_{3} \mathrm{H}_{8}$ & $\mathrm{mg} / \mathrm{m}^{3}$ & 21 & 10 & 17 & 5 & 18 & 54 \\
\hline & $\mathrm{CO}_{2}$ & $\mathrm{~g} / \mathrm{m}^{3}$ & 159 & 164 & 163 & 161 & 163 & 164 \\
\hline \multicolumn{2}{|c|}{ Degree of conv. of $\mathrm{CO}$} & $\%$ & 89.4 & 83.5 & 78.9 & 77.6 & 82.1 & 82.4 \\
\hline \multicolumn{2}{|c|}{ Degree of conv. of $\mathrm{C}_{3} \mathrm{H}_{8}$} & $\%$ & 22.0 & 12.4 & 6.3 & 32.4 & 2.0 & 15.8 \\
\hline
\end{tabular}


beech leaves briquettes in one batch. This result suggests that the shape of beech leaves briquettes (small cylinders $-0.055 \mathrm{~m}$ diameter; $0.04 \div 0.07 \mathrm{~m}$ length) is not the main reason of higher average mass concentrations of $\mathrm{CO}$ in the flue gas.

From the mass concentration of $\mathrm{C}_{3} \mathrm{H}_{8}$ point of view, flue gas produced during the standard wooden briquettes' combustion reached (on average) lower values (by approximately 23\%) than during the beech leaves briquettes' combustion. An average value of mass concentration of CO during the modes 1,3 and 5 was $21 \mathrm{mg} \cdot \mathrm{m}^{-3}$ (values ranged between $18 \mathrm{mg} \cdot \mathrm{m}^{-3}$ and 27 $\left.\mathrm{mg} \cdot \mathrm{m}^{-3}\right)$, and an average value of mass concentration of $\mathrm{CO}$ during the modes 2, 4 and 6 was $28 \mathrm{mg} \cdot \mathrm{m}^{-3}$ (values ranged between $7 \mathrm{mg} \cdot \mathrm{m}^{-3}$ and $64 \mathrm{mg} \cdot \mathrm{m}^{-3}$ ). It can be seen that the average value of beech leaves briquettes was increased only by the highest value $\left(64 \mathrm{mg} \cdot \mathrm{m}^{-3}\right)$ measured during the mode 6 . The rest of measured values during the beech leaves briquettes' combustion (modes 2 and 4 ) were the lowest of all tests.

From the mass concentration of $\mathrm{NO}_{\mathrm{x}}$ point of view (measured only at the catalyst outlet an oxidation catalyst should not have any influence at this value), flue gas produced during the standard wooden briquettes' combustion reached (on average) lower values (by approximately 60\%) than during the beech leaves briquettes' combustion.

The average value of mass concentration of $\mathrm{NO}_{\mathrm{x}}$ during the modes 1,3 and 5 was $138 \mathrm{mg} \cdot \mathrm{m}^{-3}$ (values ranged between $106 \mathrm{mg} \cdot \mathrm{m}^{-3}$ and $167 \mathrm{mg} \cdot \mathrm{m}^{-3}$ ), and an average value of mass concentration of $\mathrm{NO}_{\mathrm{x}}$ during the modes 2,4 and 6 was $340 \mathrm{mg} \cdot \mathrm{m}^{-3}$ (values ranged between $299 \mathrm{mg} \cdot \mathrm{m}^{-3}$ and $376 \mathrm{mg} \cdot \mathrm{m}^{-3}$ ). The first reason for this difference was the higher mass fraction of nitrogen in the beech leaves briquettes than in standard wooden briquettes. The second reason was the disintegration of the beech leaves briquettes on the grate during the combustion process (this caused a partial clogging of the air inlet holes on the grate), which probably caused local heat maxima, responsible for excessive origin of thermic $\mathrm{NO}_{\mathrm{x}}$.

The average of mass concentration of $\mathrm{SO}_{2}$ during modes 1,3 and 5 was under the limit of detection and the average of mass concentration of $\mathrm{SO}_{2}$ during modes 2,4 and 6 was 26 $\mathrm{mg} \cdot \mathrm{m}^{-3}$ (values ranged between $19 \mathrm{mg} \cdot \mathrm{m}^{-3}$ and $34 \mathrm{mg} \cdot \mathrm{m}^{-3}$ ). The reason for non-detection under modes 1, 3 and 5 was the small mass fraction of sulphur in the beech leaves.

Regarding the seasonal energy efficiency, its average values were the same for both tested fuels $(61 \%)$. The major heat lost, which mainly affects the efficiency, was the heat loss through sensible heat of the products of combustion, caused by high flue gas outlet temperature and high air excess ratio (high amount of flue gas).

The average heat output ranged between 4.8 and $7.5 \mathrm{~kW}$, according to the time of the mode before adding the next batch and according to the fuel net calorific value. All heat outputs achieved were in the regulatory range according to manufacturer information.

Chimney draught measured at the catalyst inlet and outlet were approximately $12 \mathrm{~Pa}$ on average.

\subsection{Degree of pollutants' conversion by tested catalysts}

As can be seen, from the degree of CO conversion point of view, CAT A worked with approximately 82.3 percentage of conversion on average of the whole combustion test $(83.5 \%$ in case of wooden briquettes' combustion and $81.2 \%$ in case of beech leaves briquettes' combustion). According to the results, the type of combusted fuel has no significant effect on degree of conversion of CO. In comparison to other catalysts, similar results were obtained during the Pd-based catalyst testing by Ryšavý et al. [26,27]. The small difference has been 
caused by different space velocity and different temperature at the catalyst inlet, which affects the catalyst's degree of conversion.

As can be seen in Table 3, from the degree of $\mathrm{C}_{3} \mathrm{H}_{8}$ conversion point of view, CAT A worked with approximately 15 percentage of conversion in average of the whole combustion test $(10.1 \%$ in case of wooden briquettes' combustion and $20.2 \%$ in case of beech leaves briquettes' combustion). According to the results, the type of combusted fuel has no significant effect on degree of conversion of $\mathrm{C}_{3} \mathrm{H}_{8}$. The result values cannot be compared with some previous results, because previous catalyst's tests were aimed at a whole OGC degree of conversion. The share of $\mathrm{C}_{3} \mathrm{H}_{8}$ in the OGC was not known and also may vary during the combustion process.

The temperature of the flue gas inside the catalyst ranged between 309 and $351{ }^{\circ} \mathrm{C}$ during all modes. The water vapor content in the flue gas ranged between 7.1 and $8.6 \%$ according to the type of fuel (due to different mass concentration of hydrogen), according to actual relative humidity of the combustion air and according to air excess ratio.

Due to the relatively high volume of catalyst itself and due to low flue gas flow, the flue gas flow ranged between approximately 40.7 and $51.8 \mathrm{~m}^{3} \mathrm{~h}^{-1}$. A low value of flue gas flow, causing low space velocity, was the reason for relatively high degree of conversion of CO. The flue gas flow through the catalysts was always laminar during all modes. Space velocity is an equivalent value to a hydraulic retention time of gas molecule inside of catalyst. It is obtained by flue gas volumetric flow rate divided by catalyst volume. Space velocity was calculated according to eqn (2):

$$
\text { space velocity }=\frac{\text { flue gas volumetric flow rate }}{\text { catalyst volume }}\left[\frac{1}{h}=\frac{\frac{m^{3}}{h}}{m^{3}}\right]
$$

There was a thin soot layer observed at the catalyst surface after the combustion tests were performed. The mass fraction of sulphur occurring in the beech leaves briquettes' composition did not cause any decrease of pollutants degree of conversion to catalyst.

\subsection{Comparison of results with current legislation}

According to the standard EN 13240:2001 [30] (currently in effect), from the mass concentration of pollutants point of view, there is a limit only aimed at $\mathrm{CO}\left(12,500 \mathrm{mg} \cdot \mathrm{m}^{-3}\right)$. The minimum efficiency limit (50\%) is also in the mentioned standard. All modes of both fuels were in accordance with the standard.

According to stricter Commission regulation (EU) 2015/1185, from the mass concentration of pollutants point of view, there are limits for CO $\left(1,500 \mathrm{mg} \cdot \mathrm{m}^{-3}\right)$, OGC $\left(120 \mathrm{mg} \cdot \mathrm{m}^{-3}\right)$, $\mathrm{NO}_{\mathrm{x}}\left(200 \mathrm{mg} \cdot \mathrm{m}^{-3}\right)$ and $\mathrm{PM}\left(40 \mathrm{mg} \cdot \mathrm{m}^{-3}\right)$. This regulation also includes limit value for seasonal heat efficiency $(65 \%)$. Values that are in accordance to this regulation are marked in green in Table 3, and values that are not in accordance with this regulation are marked in red. According to this standard only three of six modes were in accordance with CO limit (two modes with standard wooden briquettes and one mode with beech leaves briquettes), in the case when the catalyst was not used. In case of catalyst usage, the final values of all modes were well under the mentioned CO limit. The OGC limits could not be compared because 
only $\mathrm{C}_{3} \mathrm{H}_{8}$ values were measured. According to this standard, only three out of six modes were in accordance with the $\mathrm{NO}_{\mathrm{x}}$ limit (the modes with standard wooden briquettes as the fuel). Mass concentration of PM in the flue gas was not observed during the tests.

\section{CONCLUSIONS}

The results of this research proved the possibility of beech leaves briquettes usage as an alternative fuel for standard wood log stove. In the comparison of flue gas from standard wooden briquettes' combustion and beech leaves briquettes' combustion, under the same conditions, it is obvious that the biggest notable difference is in the higher mass concentration of $\mathrm{NO}_{\mathrm{x}}$ in case of the beech leaves briquettes' combustion. This disadvantage causes the mass concentration of $\mathrm{NO}_{\mathrm{x}}$ to exceed its limit value according to the current, valid legislature. A possible solution of this issue could be a co-combustion of both fuels, or briquettes production from mixed materials. The second notable deference is in the mass concentration of sulphur dioxide occurring in the flue gas produced during the beech leaves briquettes' combustion.

Both fuels struggled with the problem to meet the $\mathrm{CO}$ mass concentration limit. Oxidation palladium-based catalyst installed in the flue gas duct showed itself as a suitable solution for this problem. The low seasonal space heating efficiency reached is related mainly to stove construction (high flue gas temperature at the stove outlet). This issue could be solved by an additional heat exchanger.

In connection with catalysts, it is necessary to mention that every object inside the flue gas duct could mean a danger in a form of clogging, and the catalyst has to be regularly maintained.

Further research could be aimed at 3D CFD analysis in order to obtain additional information about the connection between the air fuel ratio and the local pollutant formation.

\section{ACKNOWLEDGEMENTS}

This work was supported by the Doctoral grant competition VŠB TU-Ostrava, reg. no. CZ.0 2.2.69/0.0./0.0/19_073/0016945 within the Operational Programme Research, Development and Education, under project DGS/TEAM/2020-035 "Determination of oxidation catalysts characteristics during the flue gas purification".

\section{REFERENCES}

[1] Bufka, A., Modlík, M. \& Veverková, J., Heat Pump Market 1981 to 2019; types, development, sales, outputs, thermal factors; TZB-info. https://vytapeni.tzb-info.cz/ tepelna-cerpadla/19284-tepelna-cerpadla-v-letech-1981-2019-druhy-vyvoj-prodejevykony-tepelne-faktory. Accessed on: 21 October 2020.

[2] The European heat pump market has achieved double-digit growth for the fourth year in a row; European heat pump association. https://www.ehpa.org/market-data/. Accessed on: 21 Oct. 2020.

[3] Climate Strategies \& Targets, 2030 Climate \& Energy Framework; European Commission, Online. https://ec.europa.eu/clima/policies/strategies/2030_en. Accessed on: 30 November 2020.

[4] Clean Heat, Residential wood burning, Environmental impact and sustainable solutions; Deutsche Umwelthilfe, Online. https://www.clean-heat.eu/en/actions/info-mate$\mathrm{rial} /$ download/background-paper-residential-wood-burning-3.html. Accessed on: 30 November 2020. 
[5] Czech Hydrometeorological Institute, Czech Republic Emission Balance. http://portal.chmi.cz/files/portal/docs/uoco/oez/embil/dokumentySpolecne.html. Accessed on: 4 January 2020.

[6] Bioenergy Europe, European Wood Pellet Consumption; European Pellet Council, Online. https://epc.bioenergyeurope.org/about-pellets/pellets-statistics/european-consumption/. Accessed on: 30 November 2020.

[7] Büfka, A., Veverková, J. \& Andronic, D., Renewable sources of energy in year 2017. Ministry of industry and trade. https://www.mpo.cz/assets/cz/energetika/statistika/ obnovitelne-zdroje-energie/2018/12/Obnovitelne-zdroje-energie-v-roce-2017-new.pdf. Accessed on: 21 October 2020.

[8] Czech pellet: healthy, comfort fuel; Česká peleta, z.s.p.o., https://www.ceska-peleta.cz/. Accessed on: 4 January 2020.

[9] Deepak, K.B., Manujesh, B.J., Vivek, A. \& Yashas, B.K., Development and study of fuel briquettes from areca leaves: A potential renewable energy source. AIP Conference Proceedings, 2080, 2019. https://doi.org/10.1063/1.5092907

[10] Khorasgani, N.B., Sengul, A.B. \& Asmatulu, E., Briquetting grass and tree leaf biomass for sustainable production of future fuels: A potential renewable energy source. Biomass Conversion and Biorefinery, 10, pp. 915-924, 2019. https://doi.org/10.1007/ s13399-019-00465-7

[11] Anggono, W., Suprianto, F.D., Gotama, G.J., Sutrisno, A. \& Evander, J., Combustion characteristics behavior of Pterocarpus indicus leaves waste briquette at various particle size and pressure. IOP Conference Series: Materials Science and Engineering, 417, 2018. https://doi.org/10.1088/1757-899X/417/1/012007

[12] Biswas, D.P., Physicochemical property and heating value analyses of charcoal briquettes from agricultural wastes: an alternative renewable energy source. International Conference on Computer, Communication, Chemical, Material and Electronic Engineering (IC4ME2). IEEE, pp. 1-5, 2018. https://doi.org/10.1109/IC4ME2.2018.8465639

[13] Hardianto, T., Pambudi, F.F. \& Irhamna, A.R., A study on lignin characteristic as internal binder in hot briquetting process of organic municipal solid waste. AIP Conference Proceedings, 1984, 2018. https://doi.org/10.1063/1.5046634

[14] Shiferaw, Y., et al., Conversion of coffee residue waste and Eucalyptus globulus leaf extract into an alternative solid fuel. Energy Sources, Part A: Recovery, Utilization, and Environmental Effects, 40, pp. 780-786, 2018. https://doi.org/10.1080/15567036.2018. 1463309

[15] Ushakov, D.E., Karelin, D.V., Bychkov, A.L., Korobeinichev, O.P. \& Shmakov, A.G., Preparation of fuel briquettes from plant biomass. Solid Fuel Chemistry, 51, pp. 238242, 2017. https://doi.org/10.3103/S0361521917040103

[16] Shuma, M.R., Madyira, D.M. \& Oosthuizen, G.A., Combustion behavior of loose biomass briquettes resulting from agricultural and forestry residues. International Conference on the Domestic Use of Energy (DUE). IEEE, 2017, pp. 38-44, 2017. https://doi. org/10.23919/DUE.2017.7931822

[17] Malak, K., et al., Green coal: A new energy source from leaves. Energy Procedia, 100, pp. 484-491, 2016. https://doi.org/10.1016/j.egypro.2016.10.207

[18] Jittabut, P., Physical and thermal properties of briquette fuels from rice straw and sugarcane leaves by mixing molasses. Energy Procedia, 79, pp. 2-9, 2015. https://doi. org/10.1016/j.egypro.2015.11.452 
[19] Yunfei, Y., et al., Experimental investigation on mixed combustion characteristics of coal, tobacco straw, and cinder in an energy-saving bake process. Journal of Energy Resources and Technology, 143(2), pp. 1-6, 2021. https://doi.org/10.1115/1.4047763

[20] Hatmojo, R.B.D., et al., Experimental study on leaf litter briquettes combustion as alternative energy source for cooking. AIP Conf. Proc., 2255, pp. 1-6, 2020. https://doi.org/ $10.1063 / 5.0013690$

[21] Ryšavý, J., et al., Beech leaves briquettes as fuel for a home combustion unit. WIT Transactions on Ecology and the Environment, Vol. 246, WIT Press, 2020, ISSN 1743541. https://doi.org/10.2495/EPM200081

[22] COMMISSION REGULATION (EU) 2015/1185: of 24 April 2015 implementing Directive 2009/125/EC of the European Parliament and of the Council with regard to ecodesign requirements for solid fuel local space heaters.

[23] Cotana, F., et al., Pollutant emissions of a biomass gasifier inside a multifuel energy plant. Atmospheric Pollution Research, 10(6), pp. 2000-2009, 2019. https://doi.org/ 10.1016/j.apr.2019.09.007

[24] Čespiva, J., et al., Characterization of tars from a novel, pilot scale, biomass gasifier working under low equivalence ratio regime. Renewable Energy, 159, pp. 775-785, 2020. https://doi.org/10.1016/j.renene.2020.06.042

[25] Atmos, Wood gasification boilers - DOKOGEN; Jaroslav Cankař a syn ATMOS, Online. https://www.atmos.eu/en/wood-gasification-boilers-dokogen/. Accessed on: 30 November 2020.

[26] Ryšavý, J., Horák, J., Hopan, F., Kuboňová, L., Krpec, K., \& Kubesa, P., Comparison of catalysts in the point of view of pellet stove flue gas purification. International Journal of Energy Production and Management, 4, pp. 124-133, 2019. https://doi.org/10.2495/ EQ-V4-N2-124-133

[27] Ryšavý, J., Horák, J., Hopan, F., Kuboňová, L., Krpec, K. \& Kubesa, P., Possibilities of reducing pollutant concetrations from biomass combustion for household heating using catalyst. Journal of Heating, Ventilation, Sanitation, 28, pp. 140-147, 2019.

[28] Reichert, G., Schmidl, C., Haslinger, W., Stressler, H., Sturmlechner, R., Schwabl, M., Wöhler, M. \& Hochenauer, C., Impact of oxidizing honeycomb catalysts integrated in firewood stoves on emissions under real-life operating conditions. Fuel Processing Technology, 177, pp. 109-118, 2018. https://doi.org/10.1016/j.renene.2017.10.065

[29] Ryšavý, J., et al., Condensation of water vapour in the flue gas path. Journal of Heating, Ventilation, Sanitation, 29, pp. 193-199, 2020.

[30] EN 13240 Room heaters fired by solid fuel - Requirements and test methods. Prague: Czech office for standards metrology and testing, 2002. 